\title{
Factor Affecting of the Diphtheria in East Java: Scoping Review by Soenarnatalina Melaniani
}

Submission date: 08-Apr-2020 07:50PM (UTC+0800)

Submission ID: 1292672437

File name: Vema_Soenarnatalina.pdf (1.27M)

Word count: 1372

Character count: 17276 


\section{Indian Journal of Public Health Research \& Development EXECUTIVE EDITOR \\ Prof Vidya Surwade \\ Associate Professor, Dr Baba Saheb Ambedkar,Medical College \& Hospital, Rohinee, Delhi}

\section{INTERNATIONAL EDITORIAL ADVISORY BOARD}

1. Dr. Abdul Rashid Khan B. Md Jagar Din, (Associate Professor) Department of Public Health Medicine, Penang Medical College, Penang, Malaysia

2. Dr. V Kumar (Consulting Physician) Mount View Hospital, Las Vegas, USA

3. Basheer A. Al-Sum, Botany and Microbiology Deptt, College of Science, King Saud University, Riyadh, Saudi Arabia

4. Dr. Ch Vijay Kumar (Associate Professor) Public Health and Community Medicine, University of Buraimi, Oman

5. Dr. VMC Ramaswamy (Senior Lecturer) Department of Pathology, Intemational Medical University, Bukit Jaili, Kuala Lumpur

6. Kartavya J. Vyas (Clinical Researcher) Department of Deployment Health Research, Naval Health Research Center, San Diego, CA (USA)

7. Prof. PK Pokharel (Community Medicine) BP Koirala Institute of Health Sciences, Nepal

\section{NATIONAL SCIENTIFIC COMMITTEE}

1. Dr. Anju Ade (Associate Professor) Navodaya Medical College, Raichur,Karnataka

2. Dr. E. Venkata Rao (Associate Professor) Community Medicine, Institute of Medical Sciences \& SUM Hospital, Bhubaneswar, Orissa.

3. Dr. Amit K. Singh (Associate Professor) Community Medicine, VCSG Govt. Medical College, Srinagar - Garhwal, Uttarakhand

4. Dr. R G Viveki (Professor \& Head) Community Medicine, Belgaum Institute of Medical Sciences, Belgaum, Kamataka

5. Dr. Santosh Kumar Mulage (Assistant Professor) Anatomy, Raichur Institute of Medical Sciences Raichur(RIMS), Karnataka

6. Dr. Gouri Ku. Padhy (Associate Professor) Community and Family Medicine, All India Institute of Medical Sciences, Raipur

7. Dr. Ritu Goyal (Associate Professor) Anaesthesia, Sarswathi Institute of Medical Sciences, Panchsheel Nagar

8. Dr. Anand Kalaskar (Associate Professor) Microbiology, Prathima Institute of Medical Sciences, AP

9. Dr. Md. Amirul Hassan (Associate Professor) Community Medicine, Govemment Medical College, Ambedkar Nagar, UP

10. Dr. N. Girish (Associate Professor) Microbiology, VIMS\&RC, Bangalore

11. Dr. BR Hungund (Associate Professor) Pathology, JNMC, Belgaum.

12. Dr. Sartaj Ahmad (Assistant Professor), Medical Sociology, Department of Community Medicine, Swami Vivekananda Subharti University, Meerut,Uttar Pradesh, India

13. Dr Sumeeta Soni (Associate Professor) Microbiology Department, B.J. Medical College, Ahmedabad, Gujarat,India

\section{NATIONAL EDITORIAL ADVISORY BOARD}

1. Prof. Sushanta Kumar Mishra (Community Medicine) GSL Medical College - Rajahmundry, Kamataka

2. Prof. D.K. Srivastava (Medical Biochemistry) Jamia Hamdard Medical College, New Delhi

3. Prof. M Sriharibabu (General Medicine) GSL Medical College, Rajahmundry, Andhra Pradesh

4. Prof. Pankaj Datta (Principal \& Prosthodentist) Indraprastha Dental College, Ghaziabad

\section{NATIONAL EDITORIAL ADVISORY BOARD}

5. Prof. Samarendra Mahapatro (Pediatrician) Hi-Tech Medical College, Bhubaneswar, Orissa

6. Dr. Abhiruchi Galhotra (Additional Professor) Community and Family Medicine, All India Institute of Medical Sciences, Raipu

7. Prof. Deepti Pruthvi (Pathologist) SS Institute of Medical Sciences \& Research Center, Davangere, Kamataka

8. Prof. G S Meena (Director Professor) Maulana Azad Medical College, New Delhi

9. Prof. Pradeep Khanna (Community Medicine) Post Graduate Institute of Medical Sciences, Rohtak, Haryana

10. Dr. Sunil Mehra (Paediatrician \& Executive Director) MAMTA Health Institute of Mother \& Child, New Delhi

11. Dr Shailendra Handu, Associate Professor, Phrma, DM (Pharma, PGI Chandigarh)

12. Dr. A.C. Dhariwal: Directorate of National Vector Borne Disease Control Programme, Dte. DGHS, Ministry of Health Services, Govt. of India, Delhi

Print-ISSN: 0976-0245-Electronic-ISSN: 0976-5506, Frequency: Quarterly (Four issues per volume)

Indian Journal of Public Health Research \& Development is a double blind peer reviewed international journal. It deals with all aspects of Public Health including Community Medicine, Public Health, Epidemiology, Occupational Health, Environmental Hazards, Clinical Research, and Public Health Laws and covers all medical specialties concerned with research and development for the masses. The journal strongly encourages reports of research carried out within Indian continent and South East Asia.

The journal has been assigned International Standards Serial Numbe (ISSN) and is indexed with Index Copernicus (Poland). It is also brought to notice that the journal is being covered by many international databases. The journal is covered by EBSCO (USA), Embase, EMCare \& Scopus database. The journal is now part of DST, CSIR, and UGC consortia.

\section{Website : www.ijphrd.com}

(c) All right reserved. The views and opinions expressed are of the authors and not of the Indian Journal of Public Health Research \& Development. The journal does not guarantee directly or indirectly the quality or efcacy of any product or service featured in the advertisement in the journal, which are purely commercial.

Editor

Dr. R.K. Sharma

Institute of Medico-legal Publications 501, Manisha Building, 75-76, Nehru Place, New Delhi-110019

Printed, published and owned by

r. R.K. Sharma Institute of Medico-legal Publications 501, Manisha Building, 75-76, Nehru Place, New Delhi-110019

Published at

Institute of Medico-legal Publications 501, Manisha Building, 75-76, Nehru Place, New Delhi-110019 


\title{
Factor Affecting of the Diphtheria in East Java: Scoping Review
}

\author{
Vema Aisya Rahma', Windhu Purnomo², Soenarnatalina Melaniani ${ }^{2}$ \\ ${ }^{1}$ Student Master; Public Health, ${ }^{2}$ Departement of Biostatistics, Faculty of Public Health, Airlangga \\ University Surabaya, Indonesia
}

\begin{abstract}
Diphtheria is an acute infectious disease caused by the Corynebacterium diphteriae bacteria. This bacterium will produce a toxin that spreads systemically and attacks the upper respiratory system and can cause damage to the respiratory epithelium. Diphtheria cases in Indonesia increased from 2016 to 2017 by 339 cases and caused outbreaks in Indonesia. The most cases are in East Java Province with the number reaching 48\%. This research is a review study. The purpose of this study was to identify the studies that had been conducted related to factors that influence the diphtheria in East Java. The results of the review show the factors that influence the diphtheria in East Java are the level of education, immunization status, physical condition of the home, population density, occupancy density, level of knowledge, and personal hygiene.
\end{abstract}

Keywords: Diphtheri, Factor Affecting, Scoping Review.

\section{Introduction}

Diphtheria is an acute infectious disease caused by the Corynebacterium diphteriae bacteria. This bacterium will produce a toxin that spreads systemically and attacks the upper respiratory system and can cause damage to the respiratory epithelium. This disease has symptoms of neck pain, fever, sore throat. Diphtheria is often characterized by the growth of a gray membrane that covers the tonsils and the respiratory tract causing difficulty breathing. Diphtheria generally attacks children aged 1-10 years ${ }^{(7,8,9)}$.

Diphtheria cases in 2016 in Indonesia were 415 cases, while diphtheria cases that died from 415 cases were 24 cases. So, the Case Fatality Rate (CFR) of diphtheria was $5.8 \%$. The highest case in Indonesia, occurred on Java Island. Reported cases of diphtheria in Indonesia, out of 415 cases, $50.2 \%$ of them did not get vaccinations. November 2017 recorded 95 regencies/cities reporting diphtheria cases and 11 provinces reporting diphtheria outbreaks in their area ${ }^{(10)}$.

\section{Corresponding Author:}

Windhu Purnomo

Departement of Biostatistics, Faculty of Public Health, Airlangga University Surabaya, Indonesia, 60115

Email: windhu-p@fkm.unair.ac.id
Diphtheria cases increased in 2017. During 2017, diphtheria outbreaks occurred in 170 regencies/cities and 30 provinces. The number of cases in 2017 reached 954 cases with 44 deaths. This case of diphtheria was found in East Java Province with a total of $48 \%{ }^{(11,12,13)}$.

With the most cases in East Java, preventive measures are needed. Prevention can be done by knowing what factors influence the diphtheria. Based on the description of the background, so the purpose of this study was to identify the studies that had been conducted related to factors that influence the incidence of diphtheria in East Java.

\section{Method}

This research is a review study. The review was carried out using an electronic database to look for research related to the case of diphtheria. Research search is limited in 2011-2017. The database used is like Google Schoolar and ProQuest. The research that will be included in this review focuses on factors in the case of diphtheria in the East Java region.

\section{Results and Discussion}

Table 1 shows the research that has been done on factors that influence the case of diphtheria in East Java. Based on the search results on the database obtained as many as six studies that meet the requirements of this review. 
Table 1: Study Literature

\begin{tabular}{|c|c|c|c|c|}
\hline Author & Year & $\begin{array}{c}\text { Design } \\
\text { Penelitian }\end{array}$ & Sample & Findings (Factor Affecting of Diphtheria) \\
\hline $\begin{array}{c}\text { Arifin, I.F. and } \\
\text { Prasastti, C.I. }\end{array}$ & 2017 & Case Control & $\begin{array}{c}\text { Case }=8 \\
\text { Control }=40\end{array}$ & $\begin{array}{c}\text { Tingkat pendidikan, status imunisasi DPT, } \\
\text { dan kondisi lingkungan fisik rumah }\end{array}$ \\
\hline Mardiana, D.E. & 2018 & Cross sectional & Secondary data & $\begin{array}{c}\text { Imunisasi dasar lengkap dan kepadatan } \\
\text { penduduk }\end{array}$ \\
\hline $\begin{array}{c}\text { Izza, N. and } \\
\text { Soenarnatalina }\end{array}$ & 2015 & Cross sectional & Secondary data & Imunisasi DPT3 \\
\hline Lestari, K.S. & 2012 & Case Control & $\begin{array}{c}\text { Case }=31 \\
\text { Control }=93\end{array}$ & $\begin{array}{c}\text { Kepadatan hunian dan pengetahuan ibu } \\
\text { Case }=78 \\
\text { Control }=78\end{array}$ \\
\hline Setiasih, A. & 2011 & Case Control $=14$ \\
Lia, A.B.G & 2011 & Case Control $=42$ & Status imunisasi \\
\hline
\end{tabular}

Based on table 1, it can be seen that the factors that influence the case of diphtheria in East Java are education level, immunization status, physical condition of the home, population density, occupancy density, level of knowledge, and personal hygiene.

Physical Environmental Conditions of Houses: The results of a review of existing studies showed that respondents who have physical environmental conditions have a relationship with high cases of diphtheria in Bangkalan Health Center in 2016 with an OR of 4.18 which means that people with physical conditions that do not meet the requirements risk 4.18 times diphtheria compared to people with environmental conditions that meet the requirements. The physical environment of this house includes many factors, namely the condition of the walls of the house, the ceiling of the house, the floor of the house, humidity, lighting, ventilation and occupancy density ${ }^{(1)}$.

Research outside East Java also showed the same results that the factors that influence the case of diphtheria are related to the home environment. The type of wall of the house has a significant relationship with the incidence of diphtheria with an OR value of 9.42. The type of floor of the house also has a significant relationship with an OR value of 20.7 which means that the type of floor is a risk factor for diphtheria ${ }^{(14)}$.

Immunization Completeness: The results of the review of existing studies indicate that respondents who did not get complete DPT immunization had a risk of developing diphtheria by 4,667 times greater than respondents who did not get complete DPT immunization ${ }^{(1)}$. The results of subsequent reviews also show that complete basic immunization can affect the prevalence of diphtheria in East Java by 0.33 times $^{(2)}$. The results of the last review, with spatial analysis showed that DPT3 immunization affected the occurrence of diphtheria. Regions that have low DPT3 immunization coverage have a high number of diphtheria ${ }^{(3)}$.

Population Density: The results of the review indicate that population density can affect the prevalence of diphtheria in East Java by 0.01 times $^{(3)}$. Population density that is not balanced with its area, can result in the emergence of slums so that it can cause infectious diseases such as diphtheria, so the higher the population density in an area, the greater the chance of the spread of diphtheria. In general, diseases that can be transmitted through direct contact occur in communities in areas with high population densities ${ }^{(15)}$. Blum ${ }^{(19)}$ states that environmental factors have a greater influence on public health compared to other factors of $45 \%$.

Education and Knowledge: The results of a review of the research conducted by Arifin (1) showed that respondents who had a low education had the risk of developing diphtheria by 1.67 times compared to respondents with high formal education. Subsequent reviews showed that the mother's poor knowledge had a risk of diphtheria of 0.088 times for diphtheria compared to good maternal knowledge $\mathrm{e}^{(5)}$.

Widyastuti ${ }^{(16)}$ states that someone who has a higher level of education will be more oriented to preventive measures, know more about health problems and also have better health status. Economic levels also have an 
influence on one's health. A person with low income will influence the level of his family's ability to meet family needs for nutrition, education and other needs ${ }^{(17)}$. Notoatmodjo ${ }^{(18)}$ states different things that income does not have a significant influence in influencing a person's health, but if someone earns quite a lot, then he is able to provide better facilities.

Personal Hygiene: The results showed that poorpersonal hygiene had a risk of 4.27 times greater for diphtheria ${ }^{(4)}$. Behavior factor is a very strong factor affecting people to be healthy or sick. Not infrequently behavior is formed due to lack of knowledge or possessing certain cultures or customs. There are people who know that exercise is important, overeating is not good but is not able to resist temptation, they are easily affected by hypertension or diabetes. There are also people or people because of their ignorance, they become sick (ignorancy) ${ }^{(20)}$.

Occupancy Density: The results of the review indicate that occupancy density that does not meet the requirements has a risk of 0.225 times for diphtheria compared to the density of occupancy that does not meet the requirements ${ }^{(5)}$. A study in West Java in 2015 also states that home density has an OR value of 22.7 which means that if most children live with a better home density, then the possibility of the child not getting diphtheria by 22.7 times $^{(21)}$. Another study in Central Java also stated the same thing that the average density of house occupants could affect the number of diphtheria cases $^{(22)}$.

\section{Conclusion}

Factors that affect the case of diphtheria in East Java are based on the results of a review of the level of education, immunization status, physical condition of the home, population density, occupancy density, level of knowledge, and personal hygiene.

\section{Acknowledgement}

On this occasion the author would like to thank the Public Health Airlangga University lecture.

Conflict of Interest: The author states that there is no conflict of interest regarding the publication of this article.

\section{Source of Funding: Self.}

Ethical Clearance: This study was approved by Health Research Ethic Committee, number 407-KEPK, Faculty of Public Health, University of Airlangga, Surabaya.

\section{REFERENCES}

1. Arifin, I.F., dan Prasasti, C.I. Faktor Yang Berhubungan Dengan Kasus Difteri Anak di Puskesmas Bangkalan Tahun 2016. Jurnal Berkala Epidemiologi. 2017; 5(1):26-36.

2. Izza, N., dan Soenarnatalina. Analisis Data Spasial Penyakit Difteri di Provinsi Jawa Timur Tahun 2010 dan 2011. Buletin Penelitian Sistem Kesehatan. 2015; 18(2):211-219.

3. Mardiana, D.E.. Pengaruh Imunisasi dan Kepadatan Penduduk Terhadap Prevalensi Penyakit Difteri di Jawa Timur. Jurnal Berkala Epidemiologi. 2018; 6(2):122-129.

4. Lia, A.B.G. Faktor Risiko Kejadian Difteri pada KLB Difteri di Sidoarjo Tahun 2010. Surabaya: FKM UNAIR; 2011. Available from: http:// repository.unair.ac.id/22941/

5. Lestari, K. S. Faktor-Faktor Yang Berhubungan Dengan Kejadian Difteri Di Kabupaten Sidoarjo. Jakarta: FKM UI; 2012. Available from: http:// lontar.ui.ac.id

6. Setiasih, A. Faktor Risiko Kejadian Difteri di Kota Surabaya Propinsi Jawa Timur. UGM; 2011. Available from: http://etd.repository.ugm.ac.id/ index.php?mod $=$ penelitian_detail \& sub $=$ Penelitian Detail \& act $=$ view \& typ $=$ html \& buku_id $=51598$

7. Puspitasari, D., Supatmini, E., dan Husada D. Gambaran Klinis Penderita Difteri Anak di RSUD Dr. Soetomo (Clinical Features of Children with Diphtheria on Soetomo Hospital). Jurnal Ners. 2012; 2(2):136-141.

8. Faidah, D.Y. dan Pontoh, R.S. Model Hurdle Poisson pada Faktor-Faktor yang Mempengaruhi Kejadian Difteri. Prosiding Seminar Nasional MIPA 2016. 2016:51-54.

9. Kemenkes. Laporan Riset Kesehatan Dasar. Jakarta: BPPK Kemenkes RI; 2013.

10. Kemenkes. Profil Kesehatan Indonesia Tahun 2016. Jakarta: Kemenkes RI; 2017. 
2712 Indian Journal of Public Health Research \& Development, October 2019, Vol.10, No. 10

11. Kemenkes. Pemerintah Optimis KLB Difteri Bisa Teratasi. Jakarta: Kemenkes RI; 2018.

12. Kemenkes. Prov. Jatim Siapkan ORI Difteri Bulan Depan. Jakarta: Kemenkes RI; 2018.

13. Kemenkes. Bulletin Kesehatan: Imunisasi Efektif Cegah Difteri. Jakarta: Kemenkes RI; 2017.

14. Kartono, B., Purwana, R., dan Djaja, I.M. Hubungan Lingkungan Rumah dengan Kejadian Luar Biasa (KLB) Difteri Di Kabupaten Tasikmalaya (2005-2006) dsn Garut Januari 2007, Jawa Barat. Makara Kesehatan. 2008:12(1);8-12.

15. Notoadmodjo, S. Kesehatan Masyarakat Ilmu dan Seni. Jakarta: Rineka Cipta; 2007.

16. Widyastuti, P. Epidemiologi Suatu Pengantar, Edisi 2, Jakarta: EGC; 2005.

17. Afifaturochmah, S., Qur'aniati, N., dan Kristiawati. Preventive Service Dan Preventive Health Education Berdasarkan Tannahill's Model Meningkatkan Perilaku Ibu Dalam Pencegahan
Difteri Pada Anak Di Wilayah Kerja Puskesmas Gading Surabaya. Critical \& Medical Surgical Nursing Journal. 2014: 3(1); 85-93.

18. Notoatmodjo, S. Pengantar Pendidikan Kesehatan dan Ilmu Perilaku. Yogyakarta: Andi Offset; 2003.

19. Blum, H.L. Planning For Health. Second Edition, New York: Human Scence Press; 1974.

20. Kayame, R. dan Pongtiku, A. Ilmu Kesehatan Masyarakat Belajar dari Lapangan. Jakarta: Nulisbuku.com; 2006.

21. Pontoh, R.S. dan Faidah, D.Y. Penerapan Hurdle Negative Binomial pada Data Tersensor. Seminar Nasional Matematika dan Pendidikan Matematika. Yogyakarta: UNY; 2015.

22. Pontoh, R.S. dan Faidah, D.Y. Model Hurdle Poisson pada Faktor-Faktor yang Mempengaruhi Kejadian Difteri. Prosiding Seminar Nasional MIPA 2016. Jatinangor: UNPAD; 2016. 
Factor Affecting of the Diphtheria in East Java: Scoping Review

ORIGINALITY REPORT

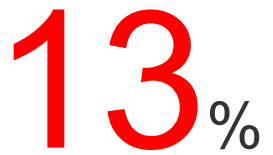

SIMILARITY INDEX
$7 \%$

INTERNET SOURCES
$5 \%$

PUBLICATIONS
$4 \%$

STUDENT PAPERS

PRIMARY SOURCES

1 www.indianodig.com

Internet Source

2 anthropologicalstudy.blogspot.com

Internet Source

3 Sumeet Dixit, Praveen K.Tyagi, Amit K.Singh,

Sudhir K.Gupta, Nidhi Malik. "CLINICO-

EPIDEMIOLOGICAL PROFILE OF ROAD

TRAFFIC INCIDENTS ADMITTED AT A

TERTIARY CARE HOSPITAL IN GARHWAL-

UTTARAKHAND", Journal of Evolution of

Medical and Dental Sciences, 2012

Publication

Avapati Raja Sekhar, Ravi Kiran Narukurthi,

Siva Kumar B, Kiran Deedi M. "Role of Serum

Uric Acid in the Assessment of Stroke", Journal

of Evolution of Medical and Dental Sciences,

2020

Publication

Submitted to EDMC 
7 Tyler C Smith, Margaret A K Ryan, Deborah L Wingard, Donald J Slymen, James F Sallis,

Donna Kritz-Silverstein. "New onset and

persistent symptoms of post-traumatic stress

disorder self reported after deployment and

combat exposures: prospective population

based US military cohort study", BMJ, 2008

Publication

8 Submitted to International Medical University

9 Submitted to Penang Medical College

10 docobook.com

Internet Source

11 Submitted to Hondros College

Student Paper

12 www.vsrdjournals.com

Internet Source

13 Santwana Mantri, E. Venkata Rao, Pradeep

Kumar Jena, Prakash Chandra Mohapatra.

"Association of CD34+ and CD90+ Stem Cells of Cord Blood with Neonatal Factors: A Crosssectional Study", The Indian Journal of 
Pediatrics, 2015

Publication

14 panchayat.gov.in

Internet Source

$1 \%$

15 apcbooks.co.in 
Factor Affecting of the Diphtheria in East Java: Scoping Review

GRADEMARK REPORT

FINAL GRADE

$/ 100$

PAGE 1

PAGE 2

PAGE 3

PAGE 4

PAGE 5

PAGE 6
GENERAL COMMENTS

Instructor 